\title{
The bipolar bivalve Oxytoma (Palmoxytoma) cygnipes (Young \& Bird, 1822) in the Upper Pliensbachian of Germany
}

\author{
Gernot Arp $\cdot$ Stephan Seppelt
}

Received: 8 March 2011 / Accepted: 3 June 2011/Published online: 23 June 2011

(C) The Author(s) 2011. This article is published with open access at Springerlink.com

\begin{abstract}
The morphologically conspicuous bivalve Oxytoma (Palmoxytoma) cygnipes (Young \& Bird, 1822), known for its palaeogeographically bipolar distribution, from a limestone bed in the boundary "BelemnitenSchichten"/Amaltheenton formation, Lower Jurassic, in N Germany is described. The occurrence of this palaeoceanographically significant bivalve points to an influx of cool seawater from the Arctic to the North-German Basin at the base of the Upper Pliensbachian, just before the deposition of the Amaltheenton formation. A review of previously reported occurrences on the NW European Shelf indicates two distinct stratigraphic intervals of occurrence of this taxon: the Rhaetian-Hettangian boundary and the Upper Pliensbachian. Whereas the former interval of occurrence may be related to short-term cooling in the course of the end-Triassic extinction event, the latter is interpreted as reflecting the influx of a cool water current to the eastern part of the NW European Shelf, which continued southwards parallel to the coast of the Bohemian-Vindelician High.
\end{abstract}

Keywords Bivalvia · Germany · Triassic-Jurassic boundary $\cdot$ Pliensbachian $\cdot$ Boreal

Kurzfassung Die morphologisch markante, bipolar verbreitete Muschel Oxytoma (Palmoxytoma) cygnipes

G. $\operatorname{Arp}(\square)$

Geowissenschaftliches Zentrum der Universität Göttingen, Goldschmidtstrasse 3, 37077 Göttingen, Germany

e-mail: garp@gwdg.de

S. Seppelt

Platz 3, 31079 Wrisbergholzen, Germany
(Young \& Bird, 1822) wird von einer Kalksteinbank an der Grenze "Belemnitenschichten"/Amaltheenton-formation, Unterer Jura, Norddeutschland beschrieben. Das Auftreten dieser paläoozeanographisch bedeutsamen Muschel deutet auf einen Einbruch kühlen Meerwassers aus der Arktis in das Norddeutsche Becken an der Basis des Oberen Pliensbachiums hin, knapp vor der Ablagerung der Amaltheenton-formation. Eine Übersicht bisher publizierter Vorkommen auf dem NW-Europäischen Schelf belegt, daß dieses Taxon auf zwei stratigraphische Intervalle beschränkt ist, und zwar den Rhaetium-HettangiumGrenzbereich und das Obere Pliensbachium. Während das Vorkommen des ersteren Intervals mit einer kurzfristigen Abkühlungsphase im Zuge des Aussterbeereignisses am Ende der Triaszeit stehen könnte, wird das letztere Vorkommen als Resultat einer Kaltwasserströmung auf den östlichen Teil des NW-Europäischen Schelfs gedeutet, welche dann weiter südwärts parallel der Küste des Böhmisch-Vindelzischen Landes verlief.

Schlüsselwörter Bivalvia $\cdot$ Deutschland .

Trias-Jura-Grenze $\cdot$ Pliensbachium $\cdot$ Boreal

\section{Introduction}

Oxytoma (Palmoxytoma) is one of the morphologically most conspicuous Jurassic bivalves. The bivalve resembles "a stretched wing of a bat" (Wetzel in Hölder 1953) and is "one of the most beautiful morphotypes of England, showing the inequality of valves so conspicuous" (Quenstedt 1867: 616). Oxytoma (Palmoxytoma) is regarded as dwelling in cool-water habitats and has a striking bipolar palaeogeographic distribution pattern in the Hettangian, with restriction to the Boreal Realm later in the Sinemurian 
and Pliensbachian (Damborenea 1993, 2002). At that time, i.e., the Sinemurian-Pliensbachian, the NW European Shelf underwent significant palaeoceanographic changes with the opening of a marine strait connecting the Arctic Ocean in the North with the Tethys in the South (Ziegler 1988, 1990; Bjerrum et al. 2001). Although the exact timing of the opening of the Transcontinental Laurasian Seaway is under discussion (Ziegler 1988; Richards 1990; Steel and Ryseth 1990; Dore 1991; Bjerrum et al. 2001), there is clear evidence from palynomorphs of cool water ingression into the Spinatum Zone of the Late Pliensbachian (van de Schootbrugge et al. 2005).

In this paper, we report the discovery of the bivalve Oxytoma (Palmoxytoma) cygnipes (Young and Bird, 1822) in the lowermost Margaritatus Zone of the Upper Pliensbachian in Beierstedt, Northern Germany. Although previously found in the Lower Jurassic of Northern Germany by von Seebach (1864) and Brauns (1871), this species is documented for the first time from a distinct stratigraphic horizon of a detailed section, and its palaeoceanographic significance is discussed.

\section{Materials and methods}

Five valves of Oxytoma (Palmoxytoma) cygnipes (Young and Bird, 1822) have been recovered during a sampling campaign in August 2006. Bivalve specimens were prepared using a variety of pneumatic preparation chisels and pens. Seventeen thin-sections $(7.5 \times 10 \mathrm{~cm})$, together covering the complete limestone beds and concretions, were prepared.

Repository: The material is stored in the Museum and Collection of the Geoscience Centre, University of Göttingen (GZG).
Location and geological overview

The investigated section at Beierstedt (sheet 3931 Jerxheim R: 3627 000; H: 5771 650) is located $20 \mathrm{~km}$ southeast of Braunschweig, south of the abandoned railway BörßumHedeper-Jerxheim (Fig. 1). The area is located at the eastern margin of the Lower Saxony Basin, a $300 \mathrm{~km}$ long and $65 \mathrm{~km}$ wide depression with a sedimentary succession from the Lower Permian Rotliegend Group to Tertiary formations (Ziegler 1990) up to $5 \mathrm{~km}$ thick. Salt cushions and diapirs rising from the Upper Permian Zechstein Group resulted in numerous salt anticlines and synclines, with a number of unconformities, mainly in the Buntsandstein Group and between Cretaceous formations. The Beierstedt section is located on the southern slope of the AsseHeeseberg salt anticline (Fig. 1). There, Hettangian to Pliensbachian strata, which are unconformably overlain by Hauterivian strata, dip with an angle of approximately $5^{\circ}$ to the SW. To date, no formal formation names have been established for the North-German Lias Group (Mönnig 2005), so traditional, informal lithostratigraphic units are used in this paper.

The Pliensbachian section at Beierstedt

More than $60 \mathrm{~cm}$ of unfossiliferous, bluish-dark grey claystones of the Upper Sinemurian "RaricostatenSchichten" (equivalent to the South German Obtususton Formation) are exposed at the base of the section at Beierstedt (Fig. 2; Table 1). The total thickness of the "Raricostaten-Schichten" at this locality is approximately $21 \mathrm{~m}$, as demonstrated by the Wetzleben drill core (Thomas 1924).

Above, the Pliensbachian starts with the $45-50 \mathrm{~cm}$ thick "Belemniten-Schichten" (equivalent to the South German
Fig. 1 Geological map of the study area showing the location of the section Beierstedt and further locations mentioned in the text

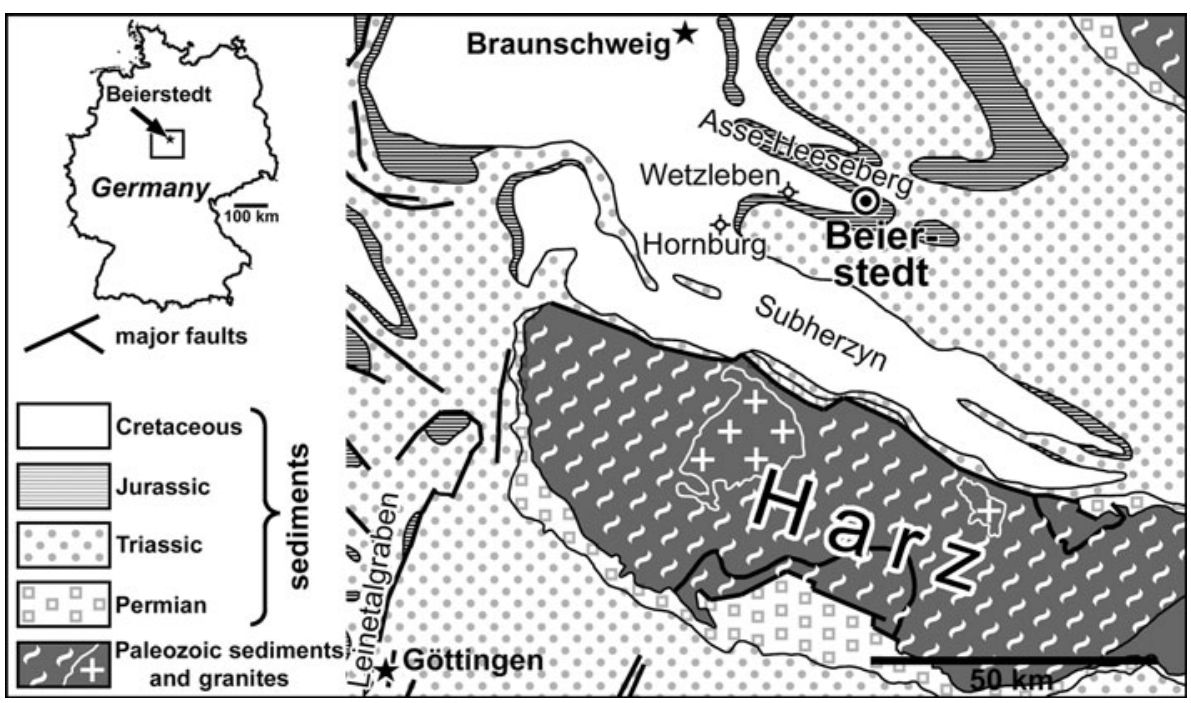


Fig. 2 Columnar section of the "Belemniten-Schichten" at Beierstedt, with the position of Oxytoma (Palmoyxtoma) cygnipes (Young \& Bird, 1822)

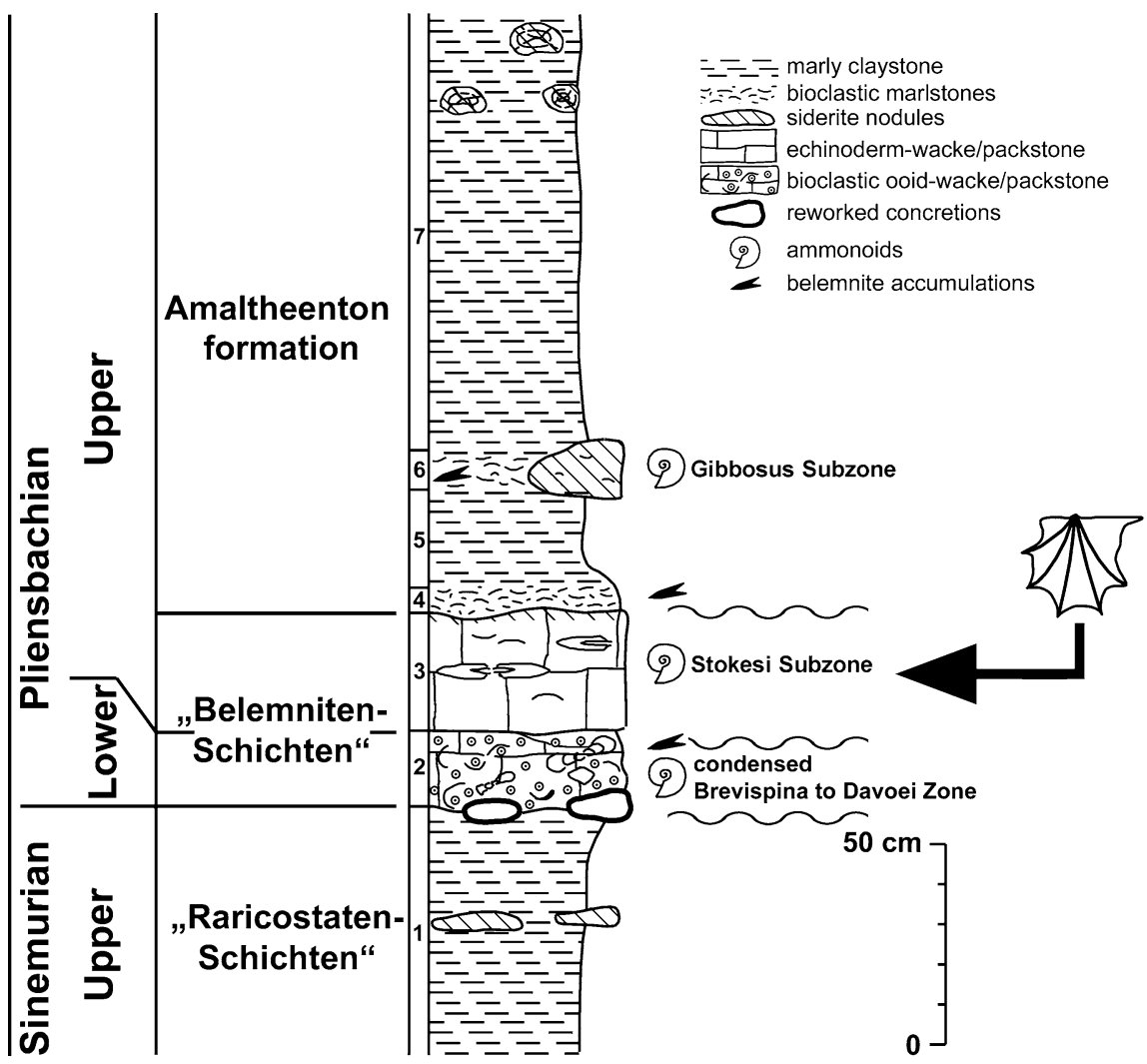

Numismalismergel Formation). The lower part of this highly condensed formation is formed by a 15-20 cm thick, highly fossiliferous limestone bed, a bioturbated bioclastic iron-ooid wackestone to packstone (Fig. 3a, b). It contains abundant echinoderm clasts, brachiopod and bivalve shell fragments (among them inoceramid shell fragments with prismatic structure), rotaliid foraminifera, and belemnite rostra bioeroded by endoliths. The $300-400 \mu \mathrm{m}$ sized ooids have siderite-replaced nuclei with limonitic cortices; locally calcitic cortices with radial crystallites also occur. Most conspicuous are $\mathrm{cm}$ to $\mathrm{dm}$-sized grey micritic concretions with round borings $8-10 \mathrm{~mm}$ in diameter. These concretions are reworked from the underlying "Raricostaten-Schichten" and indicate a discontinuity at the base of the formation. Besides abundant belemnites, bivalves, gastropods, and brachiopods, well preserved ammonoids occur, which indicate the Brevispina to Maculatum Subzones, with a possible lack of the Taylori to Polymorphus Subzones (Fig. 2; Table 1). The upper part of the "Belemniten-Schichten" is formed by a 26-30 cm thick limestone bed, composed of a bioturbated echinoderm packstone with scattered other bioclasts and rotaliid foraminifera (Fig. 3c, d). Generally, the bioclasts are smaller than in the bed below, and more corroded. Locally, $\mathrm{cm}$-sized, matrix-supported patches occur, indicating bioturbation. Macrofossils (ammonites, belemnites, bivalves) are generally well preserved, with only minor signs of corrosion, and embedded subhorizontally.
The lower bedding plane shows Amaltheus stokesi (Sowerby, 1818), Androgynoceras maculatum (Young \& Bird, 1822), and Prodactylioceras davoei (Sowerby, 1822) representing the condensed Maculatum and Stokesi Subzones, whereas major parts of the bed contain Amaltheus stokesi (Sowerby, 1818) and Lytoceras salebrosum Pompeckj, 1896 indicating the Stokesi Subzone. The upper surface of the bed shows limonite impregnation and sharp, discontinuous contact with the overlying marl.

The Amaltheenton formation starts with a marly packstone consisting of shell debris, belemnites, and echinoderm bioclasts, followed by claystones with thin shell debris layers, and a second shell debris packstone with siderite nodules (Fig. 2). The latter contain Amaltheus gibbosus (von Schlotheim, 1820), the index fossil of the Gibbosus Subzone; together, these shell-debris-rich marls are $40-50 \mathrm{~cm}$ thick; there is no indication of the Subnodosus Subzone, and a corresponding discontinuity is assumed for the base of the Amaltheenton formation. Of the remaining approximately $65 \mathrm{~m}$ of Amaltheenton (drill core Hornburg; Thomas 1924), only the lowermost $110 \mathrm{~cm}$ of bluish-grey, marly claystones with siderite concretions have been exposed in this section (Fig. 2).

The three formations were deposited in an open-marine mid-shelf environment, with higher siliciclastic supply in the "Raricostaten-Schichten" and Amaltheenton formation, and strongly reduced siliciclastic influx in the 
Table 1 Lithologic description of the section Beierstedt

\begin{tabular}{|c|c|c|c|}
\hline Formation & $\begin{array}{l}\text { Bed } \\
\text { No. }\end{array}$ & Thickness & Lithology \\
\hline \multirow[t]{4}{*}{ Amaltheenton } & 7 & $>110 \mathrm{~cm}$ & $\begin{array}{l}\text { Bluish-grey shaly claystone with disseminated pyrite; topmost } 30 \mathrm{~cm} \text { with reddish-brown siderite } \\
\text { nodules }\end{array}$ \\
\hline & 6 & $10 \mathrm{~cm}$ & $\begin{array}{l}\text { Grey shaly marlstone rich in mollusc and echinoderm debris, numerous belemnites, lignified } \\
\text { driftwood; locally reddish-brown siderite nodules up to } 10 \times 30 \mathrm{~cm} \text { in size; layer of cm-sized black } \\
\text { phosphorite nodules at the top of the bed; Amaltheus gibbosus (von Schlotheim), Ptychomphalus } \\
\text { expansus (Sowerby), Harpax spinosa (Sowerby), Myoconcha (Modiolina) sp. }\end{array}$ \\
\hline & 5 & $20-30 \mathrm{~cm}$ & $\begin{array}{l}\text { Grey shaly clayey marlstone with numerous layers of mollusc and echinoderm debris and slightly } \\
\text { corroded small belemnites of the Subhastites group; bioturbated fabric because of small branching } \\
\text { burrows }\end{array}$ \\
\hline & 4 & $5-10 \mathrm{~cm}$ & $\begin{array}{l}\text { Grey shaly marlstone rich in mollusc and echinoderm debris, numerous belemnites; Amaltheus sp.; } \\
\text { Harpax spinosa (Sowerby) }\end{array}$ \\
\hline \multirow[t]{2}{*}{$\begin{array}{l}\text { "Belemniten- } \\
\text { Schichten" }\end{array}$} & 3 & $26-30 \mathrm{~cm}$ & $\begin{array}{l}\text { Grey, weathering yellow-brown, bioturbated bioclastic limestone, divided by a joint into an upper and } \\
\text { lower part; upper part with Amaltheus stokesi (Sowerby) and Lytoceras salebrosum Pompeckj; } \\
\text { middle joint plane with Amaltheus stokesi (Sowerby), Pleurotomaria sp., Oxytoma (Palmoxytoma) } \\
\text { cygnipes (Young \& Bird), Eopecten velatus (Goldfuss), Camptonectes subulatus (Münster in } \\
\text { Goldfuss), Pseudopecten equivalvis (Sowerby), Myoconcha (Modiolina) decorata (Münster in } \\
\text { Goldfuss), lignified driftwood; lower bedding plane with numerous ammonoids; Amaltheus stokesi } \\
\text { (Sowerby), Androgynoceras maculatum (Young \& Bird), Prodactylioceras davoei (Sowerby), } \\
\text { Liospiriferina rostrata (von Schlotheim), Pseudopecten equivalvis (Sowerby) }\end{array}$ \\
\hline & 2 & $15-20 \mathrm{~cm}$ & $\begin{array}{l}\text { Grey, weathering yellow-brown, bioturbated oolitic limestone; ferruginous ooids dominate at the base, } \\
\text { calcareous ooids in top parts; highly fossiliferous; lowermost part clayey; erosive undulating lower } \\
\text { boundary; Androgynoceras maculatum (Young \& Bird) abundant within one lense at the top, } \\
\text { Beaniceras luridum (Simpson), Liparoceras (Liparoceras) cheltiense (Murchison); Uptonia sp., } \\
\text { Platypleuroceras brevispina (Sowerby. ( } 5 \mathrm{~cm} \text { above base); Lytoceras fimbriatum (Sowerby), } \\
\text { Tragophylloceras loscombi (Sowerby), Liospiriferina rostrata (von Schlotheim), Pseudokatosira cf. } \\
\text { undulata (Benz), Pinna hartmanni Zieten, Parainoceramus ventricosus (Sowerby), Entolium lunare } \\
\text { (Roemer), Pseudopecten equivalvis (Sowerby), Camptonectes subulatus (Münster in Goldfuss), } \\
\text { Eopecten velatus (Goldfuss), Chlamys textoria (von Schlotheim), "Avicula" calva (Schloenbach), } \\
\text { Terquemia difformis (von Schlotheim), Antiquilima succincta (von Schlotheim), Plagiostoma } \\
\text { gigantea (Sowerby), Pseudolimea pectinoides (Sowerby), Gryphaea gigantea (Sowerby), } \\
\text { Myoconcha (Modiolina) decorata (Münster in Goldfuss), Astarte sp., Cardinia rugulosa Tate, } \\
\text { Pholadomya ambigua (Sowerby), Pleuromya costata (Young \& Bird), Pleuromya ovata (Roemer), } \\
\text { Pleuromya meridionalis Dumortier }\end{array}$ \\
\hline
\end{tabular}

"Raricostaten- $\quad 1 \quad>60 \mathrm{~cm} \quad$ Bluish-grey shaly claystone with one layer of reddish-brown siderite nodules ca. $25 \mathrm{~cm}$ below top, no Schichten" macrofossils observed

"Belemniten-Schichten". Contrary to previous assumptions (Thomas 1924), there is no indication of a highenergy shallow water or coastal environment. A detailed description of the section is given in Table 1 .

Systematic palaeontology

Order Pterioida Newell, 1965

Family Oxytomidae Ichikawa, 1958

Genus Oxytoma Meek, 1864

Subgenus Palmoxytoma Cox, 1961

Type species: Pecten cygnipes Young \& Bird, 1822, from the ironstone bands of the aluminous strata, Yorkshire, by original designation.

Oxytoma (Palmoxytoma) cygnipes (Young \& Bird, 1822) (Fig. 4a-g)
*1822 Pecten cygnipes; Young \& Bird: 235, pl. 9/fig. 6 1828 Pecten cygnipes; Young \& Bird: 236, pl. 9/fig. 3

1829 Avicula cygnipes; Philipps: 162, pl. 14/fig. 3

1839 Avicula longicostata, Stutch.; Stutchbury: 163, fig. 1856 Avicula cygnipes; Oppel: 179

1857 Avicula cycnipes (Phillips); Dumortier: 7-10, pl. 4/figs. 1-4

1864 Avicula cygnipes Young and Bird; von Seebach: 103

1867 Avicula cygnipes Phill.; Quenstedt: 616, pl. 59/fig. 5

1869 Avicula cycnipes (Phillips); Dumortier: 294-297, pl. 35/figs. 6-9

1871 Avicula cygnipes; Brauns: 359

1876 Monotis cygnipes Young and Bird; Tate and Blake: 370-371

1881 Avicula (Oxytoma) magnifica n.sp.; Lundgren: 19, pl. 5/figs. 2-5 

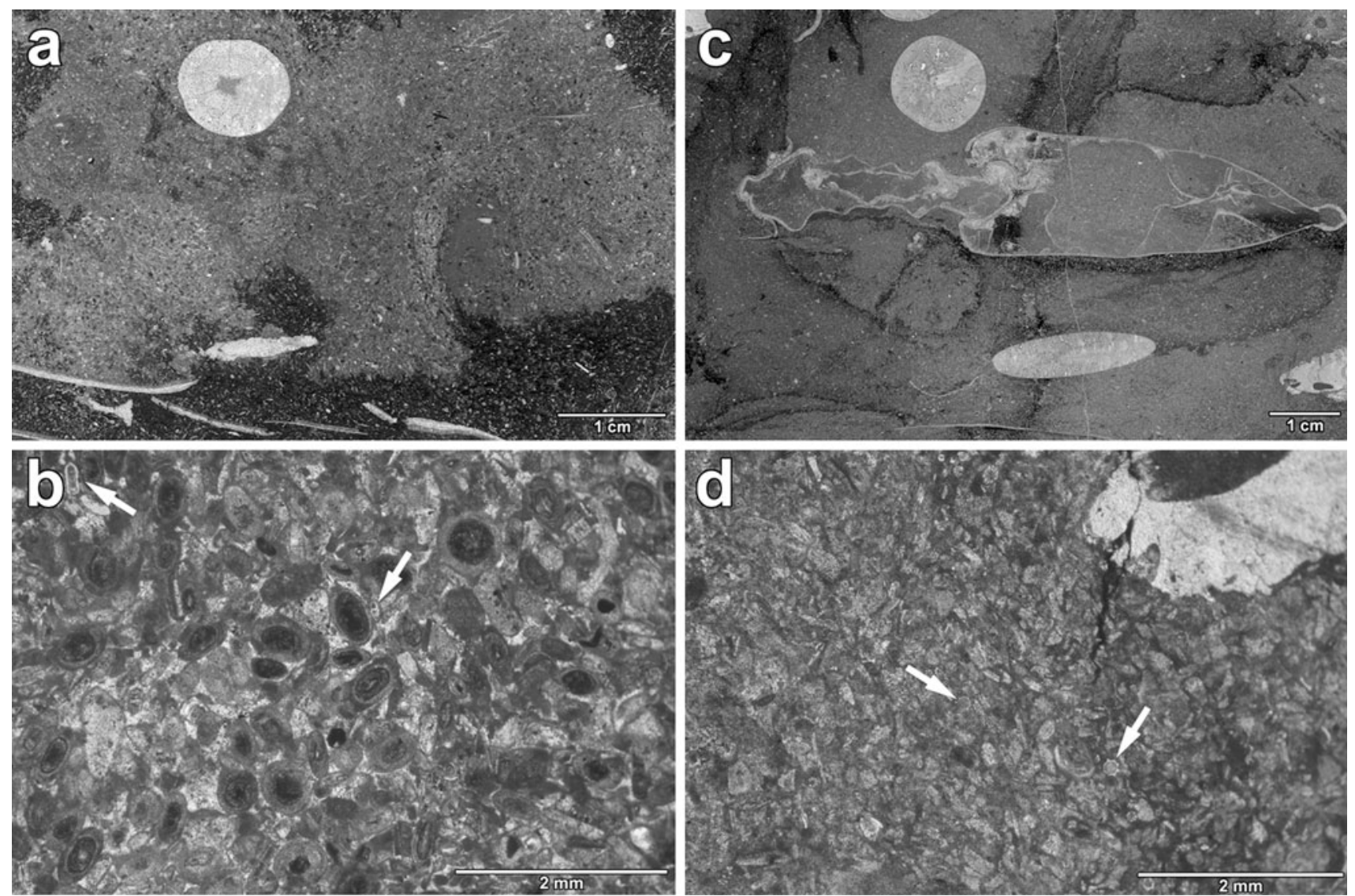

Fig. 3 Microfacies of the "Belemniten-Schichten", condensed Lower Pliensbachian and Stokesi Subzone of Beierstedt. a Overview of bioclastic iron-ooid wackestone to packstone of bed 2, Lower Pliensbachian, with belemnite rostra and bivalve shells. Note intense bioturbation. b Detail of a showing ooids with ferrugineous inner and calcareous outer cortices, bioclasts, and rotaliid foraminifera

(arrows). c Overview of bioturbated echinoderm packstone of bed 3. Note cross-section of several belemnite rostra and an Amaltheus stokesi (Sowerby, 1818). d Detail of c showing densely packed echinoderm clasts, a corroded belemnite fragment, and scattered rotaliid foraminifera (arrows)

1888 Avicula scanica L.; Lundgren: 18

1888 Avicula anserina n. sp.; Moberg: 38, pl. 3/fig. 18

1891 Avicula cygnipes; von Gümbel: 379

1891 Avicula cygnipes Phill.; von Ammon in von Gümbel: 690

1906 Avicula cygnipes Phil.; Fugger: 231

v 1907 Avicula cygnipes Phill.; von Koenen: 44

non 1911 Oxytoma inaequivalve Sow. aff. cycnipes

Phill. (Y. \& B.); Hahn: 541, pl. 20/fig. 2

1913 Avicula (Oxytoma) cf. cycnipes, Phill.; Jeannet:

367, fig. 25

? 1923 Oxytoma sp.; Trechmann: 272, pl. 12/figs. 6-7

1933 Oxytoma longicostata (Strickland); Arkell: 602, pl.

29/fig. 1

? 1934 Oxytoma cf. cygnipes Y. et B.; Rosenkrantz: 51,

117

1934 Oxytoma cygnipes Y. et B.; Rosenkrantz: 112

v 1935 Oxytoma cf. longicostata Strickl.; Kuhn: 2, pl. 2/fig. 6

1951 Oxytoma scanica (Lundgren); Troedsson: 201, pl. 10/fig. 15

v 1953 Oxytoma scanica (Lundgren 1888); Hölder: 359, fig. 1

1957 Oxytoma cygnipes Phillips; Frebold: 67, pl. 16/figs. $1-5$

1961 Oxytoma (Palmoxytoma) cygnipes (Young \& Bird 1822); Cox: 593

1964 Oxytoma cf. cygnipes (Phillips); Hölder: 432, fig. 126

1967 Oxytoma (Palmoxytoma) cygnipes (J. Sow.); Hallam: 400

1968 Oxytoma cygnipes (Young et Bird), 1822; Efimova et al.: 46, pl. 22/figs.11-12

1976 Oxytoma (Palmoxytoma) cygnipes (Young \& Bird); Milova: 53, pl. 4/fig. 6, pl. 5/figs. 2-5

1991 Oxytoma (Palmoxytoma) cygnipes (Young and Bird); Poulton: 26, pl. 11/figs. 14-16

? 1991 Palmoxytoma sp.; Riccardi et al.: 166, fig. 4/14 

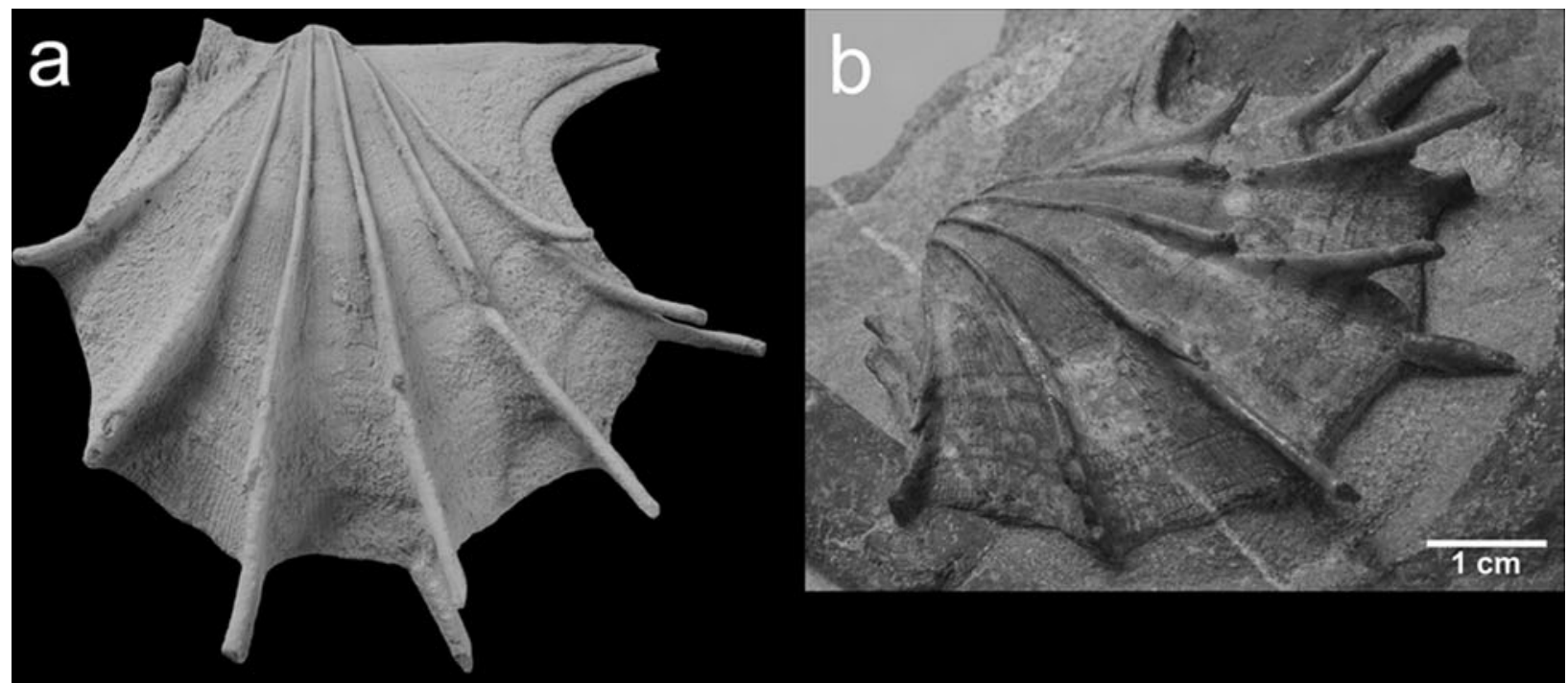

C
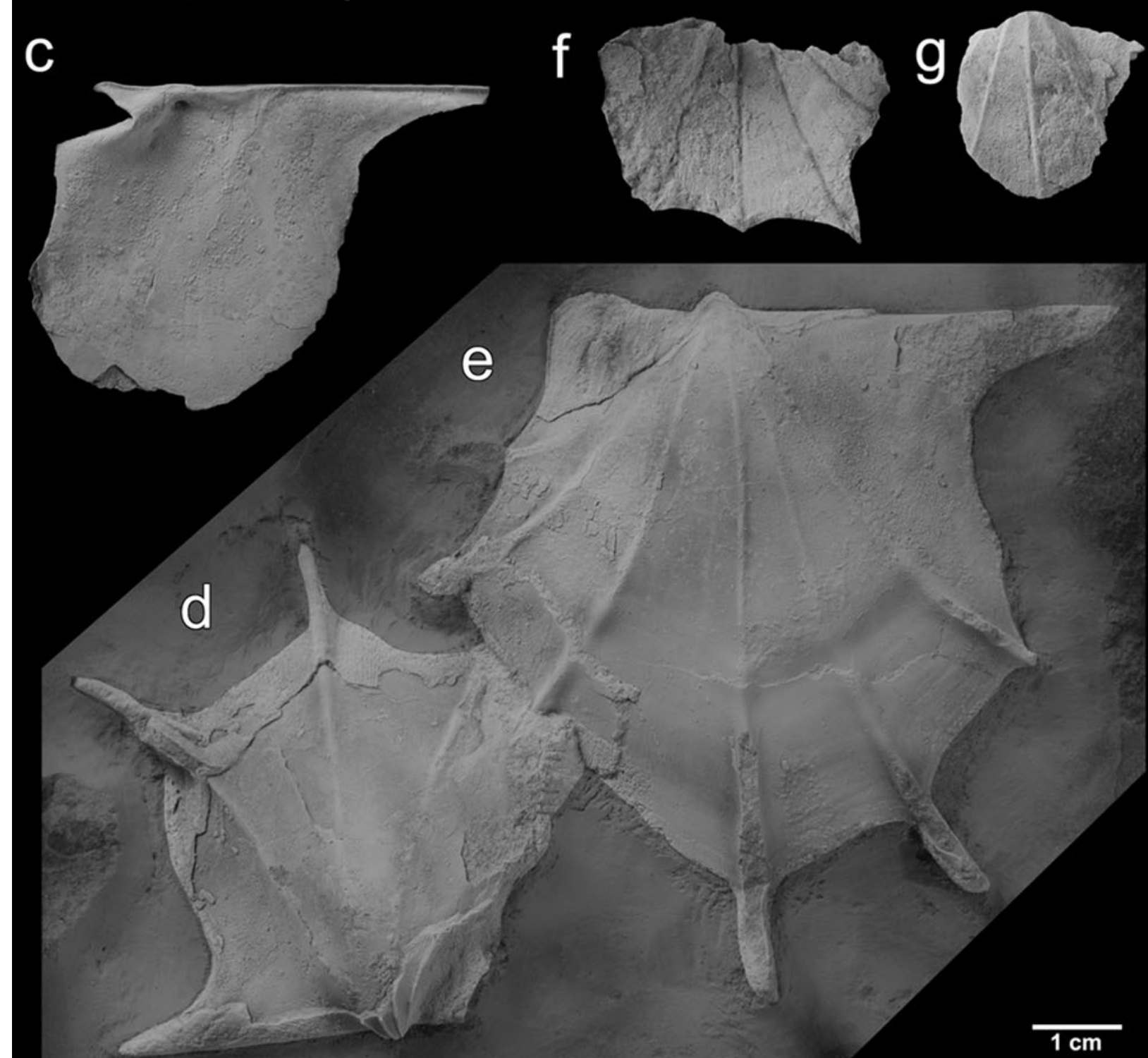
4 Fig. 4 Oxytoma (Palmoxytoma) cygnipes (Young \& Bird, 1822) from the top of the "Belemniten-Schichten", Stokesi Subzone, Lower Saxony. a, b External view of left valve showing spines. Bed 3, Beierstedt. GZG.INV. 31004. c Internal view of right valve. Bed 3, Beierstedt. GZG.INV. 31005. d Internal mould of left valve with spine-like rib projections. Bed 3, Beierstedt. GZG.INV. 31002. e Internal mould of left valve with spine-like rib projections. Bed 3, Beierstedt. GZG.INV. 31001. f, g Fragmentary internal mould and negative imprint of left valve. Top of "Belemniten-Schichten", Göttingen-Geismar. GZG.INV. 30576 a \& b

? 1992 Palmoxytoma sp.; Damborenea and Mancenido: 132, pl. 1/fig. 1

1992 Oxytoma (Palmoxytoma) cygnipes; Sey et al.: 228 1994 Oxytoma (Palmoxytoma) cf. cygnipes; Aberhan: 35, Text-fig. 16

1997 Palmoxytoma sp.; McRoberts et al.: 82, 87

1998 Oxytoma (Palmoxytoma) cygnipes (Young \& Bird 1822); Aberhan: 95, pl. 9/fig. 15-16, 18-19

2002 Palmoxytoma cf. cygnipes (Young \& Bird 1822); Damborenea: 23, pl. 1/figs. 6-8

? 2002 Palmoxytoma n. sp.; Damborenea: 23, Text-fig. 9 2004 Oxytoma (Palmoxytoma) ussurica Voronetz; Konovalova and Markevich, pl. 21/figs. 1-7

2007 Oxytoma (Palmoxytoma) cygnipes (Young \& Bird); Rulleau: 82, pl. 52/5

Material: One right complete, three left complete, and one left incomplete valves from bed 3 (Upper Pliensbachian, Stokesi Subzone) of the "Belemniten-Schichten" at Beierstedt. One incomplete internal mould and corresponding external imprint of a left valve from the "Gamma-DeltaGrenzbank" (Upper Pliensbachian, Stokesi Subzone), top of "Belemniten-Schichten" of Göttingen-Geismar.

Description: Shell medium-sized, very inequivalve with left valve convex and right valve almost flat. Shape suborbicular, equilateral to slightly opistocline. Hinge long and straight, with a wing-like posterior auricle and a small anterior auricle. Right valve anterior auricle triangular and separated from valve by deep byssal notch. Ligament groove long and narrow. Right valve with umbo not protruding and slightly prosogyrous, faint ornamentation consisting of fine radial striae. Left valve with umbo slightly protruding and ornamentation consisting of 4-6 prominent radial ribs separated by areas with fine radial riblets. Main ribs with ovoid to circular cross-section resting upon a thin ridge. At major growth lines, ribs grade into spines up to $15 \mathrm{~mm}$ long and projecting at the disc margin.

Measurements These are provided in Table 2.

Remarks: The species Oxytoma (Palmoxytoma) cygnipes (Young \& Bird, 1822) is derived from the CarnianNorian ancestor Oxytoma mojsisovicsi Teller, 1886 (Damborenea 1987: 160, 2002: 22). Early Hettangian representatives have been referred to as Oxytoma (Palmoxytoma) longicostata (Stutchbury, 1839) (e.g., Arkell 1933; Kuhn 1935). However, the morphological differences between $O$. (P.) longicostata and $O$. (P.) cygnipes are gradual, and reflect largely preservational effects (Fig. 4a-g). Specifically, within limestones (e.g., Psilonotenkalk; Hölder 1953) internal moulds and inside views of shells are obtained, and the spiny outer surface remains hidden within the attached matrix. This is true for our specimens also; the long projections and spines are observed only after laborious preparation (Fig. 4a, b).

Apart from that, Oxytoma (Palmoxytoma) cygnipes (Young \& Bird) has, indeed, some variability with regard to the density of ribs and the shape of the disc. Oxytoma cygnipes (Young et Bird) from Eastern Siberia described

Table 2 Measurements of Oxytoma (Palmoxytoma) cygnipes (Young \& Bird, 1822)

\begin{tabular}{|c|c|c|c|c|c|c|}
\hline Specimen & Location & Material & $L(\mathrm{~mm})$ & $H(\mathrm{~mm})$ & $I(\mathrm{~mm})$ & $R$ \\
\hline GZG.INV. 31001 & Beierstedt, Northern Germany & LV, internal mould & 65 & 65 & 9 & 6 \\
\hline GZG.INV. 31002 & Beierstedt, Northern Germany & LV, internal mould & 50 & 50 & 9 & 4 \\
\hline GZG.INV. 31003 & Beierstedt, Northern Germany & $\mathrm{LV}$, incomplete negative & $(40)$ & $(42)$ & (5) & (4) \\
\hline GZG.INV. 31004 & Beierstedt, Northern Germany & LV, shell & 50 & 47 & 9 & 6 \\
\hline GZG.INV. 31005 & Beierstedt, Northern Germany & RV, shell & 35 & 37 & 2 & - \\
\hline GZG.INV. 30576 a \& b & Göttingen, Northern Germany & LV, internal mould \& negative imprint & (18) & $(21)$ & (3) & 4 \\
\hline GZG.INV. 30577 a & Whitby, Yorkshire & LV, internal mould & 75 & 73 & 8 & 5 \\
\hline GZG.INV. 30577 b & Whitby, Yorkshire & LV, internal mould & 56 & 58 & 7 & 5 \\
\hline GZG.INV. 30577 c & Whitby, Yorkshire & $\mathrm{LV}$, internal mould & $(50)$ & 50 & 6 & 5 \\
\hline GZG.INV. 30577 d & Whitby, Yorkshire & $R V$, external mould & 48 & $(42)$ & 2 & - \\
\hline SMNS 17361 (Kuhn 1935) & Nellingen, Southern Germany & LV, internal mould & 52 & $(48)$ & 8 & 7 \\
\hline GPIT 1028/53 (Hölder 1953) & Bebenhausen, Southern Germany & $\mathrm{LV}$, internal mould & 55 & 54 & 7 & 6 \\
\hline
\end{tabular}

Numbers in brackets are approximations

$L$ length, $H$ height, $I$ inflation, $R$ number of ribs 
by Efimova et al. (1968) has only four prominent ribs. The umbo is slightly prosogyrous, and the valves are otherwise identical with the specimens described in this paper. Three left valves of Oxytoma (Palmoxytoma) cygnipes (Young \& Bird) published by Poulton (1991) are comparatively small, and hence have only four ribs. Apart from that, they are identical with our specimens in shape and ornamentation, including spine-like rib projections. A variety with seven ribs with rather close spacing has been described as $O x y$ toma (Palmoxytoma) ussurica Voronetz by Konovalova and Markevich (2004). The specimens have slightly prosogyrous umbones but the general shape and ornamentation, including spine-like rib projections, is almost identical with those of Oxytoma (Palmoxytoma) cygnipes (Young \& Bird).

More pronounced differences from the specimens from the NW European Shelf can be seen in specimens from South America and New Zealand. The internal mould of a right valve of Palmoxytoma cf. cygnipes (Damborenea 2002: pl. 1/8a and Riccardi 1991: fig. 4/14) from Argentina has a very deeply incised byssal notch, not observed in our specimen with shell preservation. An extreme variety from New Zealand, a specimen with only three prominent ribs and curved spines, has been illustrated by Damborenea (1993: fig. 3b, 2002: text-fig. 9) as Palmoxytoma n. sp. In addition, the disc margins between the prominent ribs are curving outward, and are not concave as in the NW European specimens with their umbrella-like appearance (cf. Troedsson 1951: 201). Further specimens of this Oxytoma (Palmoxytoma) variety are required to decide whether the low rib number is a constant feature enabling definition of a new species.

Taking these variations into account, the currently available data are consistent with the interpretation of the mentioned specimens as a single species, with morphological variations between specimens from the northern and southern hemispheres.

Biogeography of Oxytoma (Palmoxytoma) cygnipes (Young and Bird) on the Lower Jurassic NW European Shelf

On the NW European Jurassic Shelf Oxytoma (Palmoxytoma) cygnipes (Young \& Bird, 1822) occurs at two distinct stratigraphic intervals. These are the RhaetianHettangian boundary strata (Pre-Planorbis beds to Planorbis bed) and the Upper Pliensbachian (base of Marlstone Rock Formation, Staithes Sandstone, and Cleveland Ironstone Formation, Amaltheenton formation) (Table 3).

Rhaetian/Hettangian. From the British Lower Jurassic, one of the stratigraphically oldest records of Oxytoma (Palmoxytoma) cygnipes is that of Stutchbury (1839) from the Saltford Shale (Blue Lias Formation), a long-spined variety initially described as Avicula longicostata Stutchbury, 1839. A precise bed has not been identified, but the Saltwick Shale is confined to the Planorbis to lower Angulata Zones (Ambrose 2001).

Hodges in Cope (1991) mentioned Palmoxytoma from the Pre-Planorbis Beds, i.e. the basal part of the Blue Lias Formation. The precise position below or above the Rhaetian-Hettangian boundary is not clear. In addition, the Bath Royal Literary and Scientific Institution hosts several specimens of $O$. (P.) longicostata from "Lower Lias clay with White \& Blue Lias Lst.", Montpelier, Bristol (collection C. Moore). From the same location, Oxytoma longicostata has been illustrated by Arkell (1933) as a characteristic fossil of the Pre-Planorbis beds.

A further occurrence from the Rhaetian-Hettangian transition is represented by Palmoxytoma sp. from the Upper Schattwald Shales of Lorüns/Vorarlberg (McRoberts et al. 1997), above the negative $\delta^{13} \mathrm{C}$ excursion preceding the Triassic-Jurassic boundary (von Hillebrandt et al. 2007). Again, it is not clear whether the specimen is still latest Rhaetian or earliest Hettangian.

Of lowermost Hettangian age seems to be Avicula (Oxytoma) cf. cycnipes Phill. described and illustrated by Jeannet (1913). He obtained four valves of this taxon from approximately $6 \mathrm{~m}$ below the "Niveau à Planorbis" but still $20 \mathrm{~m}$ above typical Rhaetian limestones. Again, the precise position of the Rhaetian-Hettangian boundary is not evident from currently available information.

Clearly of Hettangian age are the reports of $O$. (Palmoxytoma) from the Swabian Jurassic (South Germany), i.e. findings from the Psilonoten Limestone. These are one fragmentary internal mould assigned to Oxytoma cf. longicostata Strickl. from Nellingen (Kuhn 1935) and one internal mould described as Oxytoma scanica (Lundgren, 1888) from Bebenhausen (Hölder 1953). The latter specimen is associated with Psiloceras plicatulum (Quenstedt, 1883). Recently, Schweigert and Klaschka (2011) discovered a further specimen comparable with Oxytoma (Palmoxytoma) from the Psilonoten Limestone of Bebenhausen. The Psilonoten Limestone is a $30-40 \mathrm{~cm}$ thick, condensed transgressive bed including ammonites of the lower Planorbis Zone, Psilonotum and Plicatulum horizons, locally underlain by a Neophyllites horizon (Bloos 1999). These ammonite horizons rest unconformably upon Rhaetian marine-deltaic sandstones.

Possibly younger but still within the Planorbis Zone are the youngest published occurrences from the Hettangian of the Northern Calcareous Alps. From top parts of the Hettangian Kendlbach Formation (still below Psiloceras calliphyllum (Neumayr, 1879) and Psiloceras costosum Lange, 1952) at the Ochsentaljoch section, Karwendel, von 


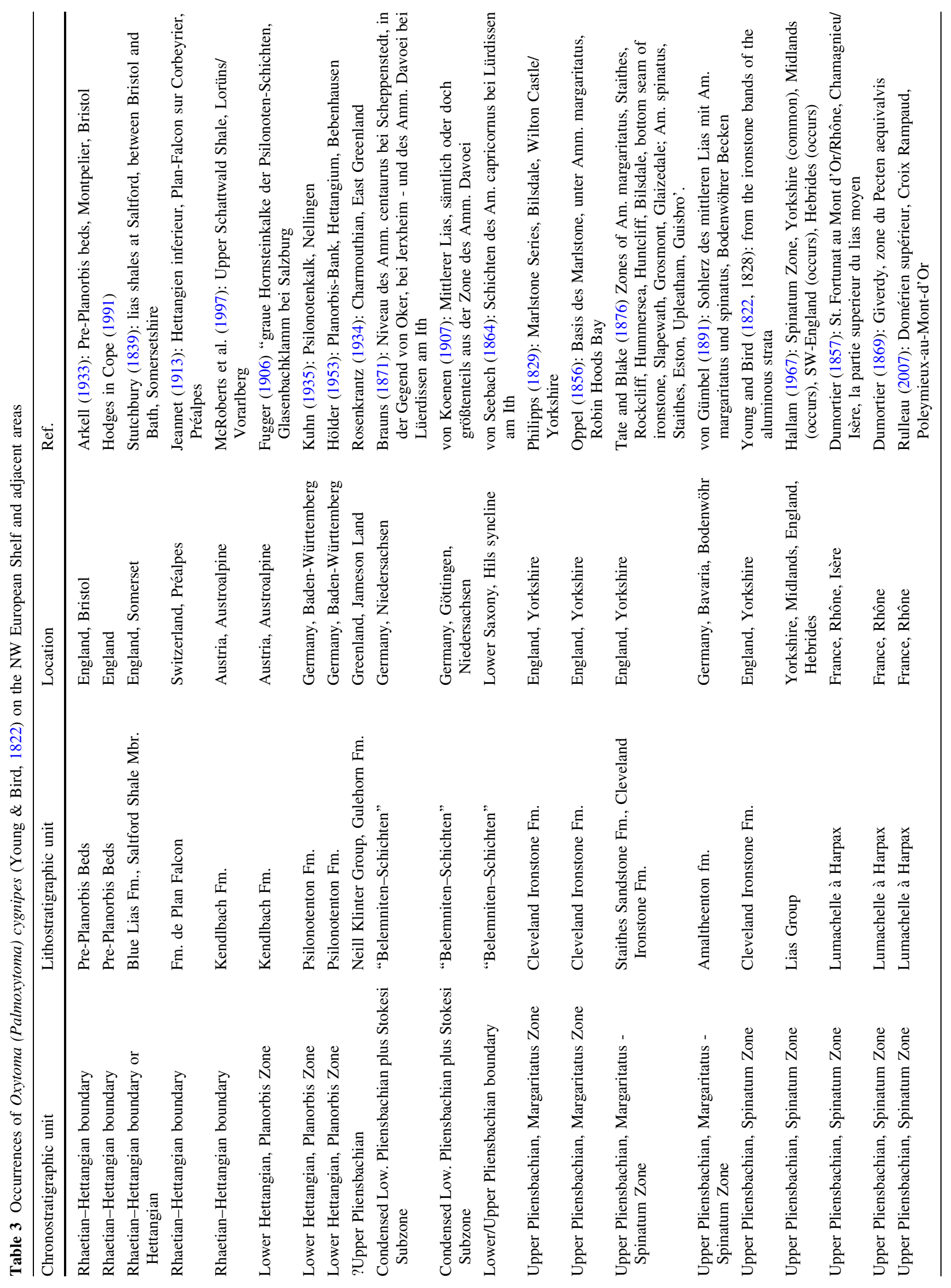


Hillebrandt et al. (2007: fig. 9) illustrated an "Oxytoma", which can be identified as the left valve of $O$. (Palmoxytoma) cygnipes. In addition, Fugger (1906) mentioned Avicula cygnipes Phil. from Lower Hettangian siliceous limestones with cherts at the Glasenbachklamm near Salzburg.

Taking all these published occurrences into account, Oxytoma (Palmoxytoma) cygnipes (Young \& Bird, 1822) seems to have been widespread in the Rhaetian-Hettangian boundary strata of the NW European Shelf and its margin to the Tethys. By contrast, the following Upper Hettangian to Lower Pliensbachian deposits of this area appear to be devoid of this species.

Pliensbachian. The type species of Young and Bird (1822) comes from the Upper Pliensbachian Cleveland Ironstone Formation ("hard bands in the alum shale"), where it is most abundant in the "Avicula seam" (i.e., top of the Subnodosus Subzone; Howarth 1955; Rawson and Wright 1996: 206). This coincides with the descriptions of Harries and Little (1999), who mention Palmoxytoma cygnipes from the upper Staithes Sandstone and Cleveland Ironstone Formations (Stokesi to Apyrenum Subzone) of the Yorkshire coast (Staithes Harbor and Saltwick Nab). Similarly, Hallam (1967) reports Oxytoma (Palmoxytoma) cygnipes (Young \& Bird, 1822) from the Spinatum Zone of Yorkshire (common), in addition to the Midlands (occurs), SW-England (occurs) and the Hebrides (occurs).

From East Greenland, Oxytoma cygnipes Y. et B. is reported by Rosenkrantz (1934: 112) from the Pliensbachian (Charmouthian), though without illustration. From the sections described and the few ammonites found, it seems possible that the fossil-bearing strata range into the Upper Pliensbachian.

Also, the early reports of Oxytoma (Palmoxytoma) from southern Sweden (Lundgren 1881, 1888) apparently show specimens from the Pliensbachian. The fine-grained sandstone that contained the Oxytoma (Palmoxytoma) specimen of Moberg (1888) is also most likely Pliensbachian in age (cf. Reyment 1959; Ahlberg et al. 2003). However, a more precise biostratigraphic designation is not available, because the material is derived from glacial till deposits (Brandsberga sandstone, Middle Liassic; Sivhed 1984).

In Northern Germany the Lower-Upper Pliensbachian boundary strata yield Palmoxytoma specimens, as noted by von Seebach (1864) and Brauns (1871). These authors mention Avicula cygnipes Young and Bird from the "Belemniten-Schichten" of the Hils syncline and Subhercynian syncline and from the margin of the AsseHeeseberg anticline (von Seebach 1864; Brauns 1871). Unfortunately, these reports are without illustration and without described sections, so the precise stratigraphic position (Davoei Zone or Stokesi Subzone), crucial for 


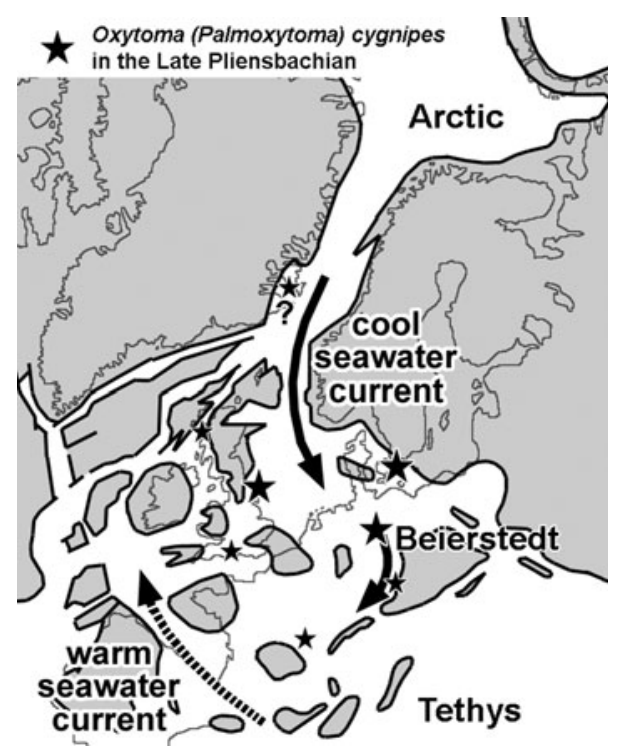

Fig. 5 Possible seawater current pattern on the NW European Shelf based on the occurrences/non-occurrences of Oxytoma (Palmoyxtoma) cygnipes (Young \& Bird, 1822) and model calculations of Bjerrum et al. (2001). Palaeogeography based on Ziegler (1988)

palaeoceanographic interpretations, in these condensed beds remains unclear. Similarly, the precise biostratigraphic level of Avicula cygnipes Phill. of von Koenen (1907: 44) from the Middle Lias of Göttingen is not clear from this publication. However, the corresponding specimen is in the GZG collection ("Avicula cycnipes Phill., M. Lias, d d [donum dedit] Wolf, Göttingen-Geismar"; Fig. 4f, g), preserved within an echinoderm packstone, which is likely to be derived from the top of the "Belemniten-Schichten", i.e. the Stokesi Subzone.

From Southern Germany, von Ammon (in von Gümbel 1891: 690) lists Avicula cygnipes from the Upper Pliensbachian iron ores of Bodenwöhr, Eastern Bavaria. These highly condensed, $0.2-1.5 \mathrm{~m}$ thick fissile goethitehaematite deposits comprise the Margaritatus and Spinatum Zones (von Gümbel 1891; Meyer and Bauberger 1998). This is currently the southeasternmost occurrence of Oxytoma (Palmoxytoma) cygnipes. Unfortunately, no corresponding specimen exists in the Gümbel collection of the Bavarian Geological Survey.

Further specimens have been discovered in southeastern France, as already described and illustrated by Dumortier (1857) from the upper part of the Pliensbachian east of Lyon (St Fortuna), and from the Upper Pliensbachian ("Zone du Pecten aequivalvis") of Giverdy in the Mont d'Or area (Dumortier 1869). In the region of Lyon, Oxytoma (Palmoxytoma) cygnipes occurs within a highly condensed limestone bed (Calcaire à Harpax) together with Gryphaea (Bilobissa) sportella (Dumortier, 1869), Cardinia crassissima (Sowerby, 1817) and rare Pleuroceras spinatum (Bruguiere 1789) and Pleuroceras solare (Phillips, 1829), pointing to the top parts of the Apyrenum Subzone of the Spinatum Zone (Louis Rulleau, personal communication).

In summary, Late Pliensbachian occurrences of the bivalve Oxytoma (Palmoxytoma) cygnipes (Young \& Bird, 1822) are evident for England, southern Sweden to southeastern Bavaria, and southeastern France (Fig. 5) whereas specimens are rare or absent on the western shelf parts of NW Europe and the Mediterranean region.

Toarcian. The only published occurrence in the Toarcian known to the authors is Oxytoma cf. cygnipes Y. et B. of Rosenkrantz (1934) from Jameson Land, East Greenland, but the taxon has not been illustrated.

\section{Discussion}

The Lower Jurassic sedimentary pattern on the NW European Shelf has predominantly been interpreted on the basis of sea-level changes being the major controlling factor (Brandt 1985; de Graciansky et al. 1998; Hesselbo and Jenkyns 1998). However, changes in the current systems may have played an equally important role. Specifically, the palaeogeographic situation of the NW European Shelf, with a narrow seaway to the North (Viking Corridor: Westermann 1993; Transcontinental Laurasian seaway: Bjerrum et al. 2001) implies that the sedimentary system of the shelf was susceptible to changes in current direction, dependent on the density differences between Arctic and Tethyian seawater (Bjerrum et al. 2001).

The Late Pliensbachian has been interpreted as a relatively cool period in NW Europe, mainly as a result of general climatic cooling in the Northern Hemisphere (Price 1999; Guex et al. 2001). Alternatively, cool water conditions, as reflected in palynomorph assemblages and $\delta^{18} \mathrm{O}$ values from belemnites, were considered to reflect influx of cool water masses from boreal regions (Riding and Hubbard 1999; van de Schootbrugge et al. 2005). In addition, there is increasing geochemical evidence that changes in current directions occurred on the NW European Shelf during the Early Jurassic (Dera et al. 2009).

In Germany, major parts of the Upper Pliensbachian are represented by the comparatively thick, monotonous succession of dark marly claystones, the Amaltheenton formation, which is dominated by macrobenthos assemblages of comparatively low diversity (see, e.g., Paleobiology Database collection numbers 23624-23628 and 23812-23818), although species listings by Brauns (1871), Monke (1889) and Kuhn (1936) give a contrary impression. By contrast, the Lower Pliensbachian of Germany contains calcareous sediments (marlstone-limestone alternations), with iron-oolitic 
intercalations in the north and phosphoritic intercalations in the south. The macrobenthos shows more diverse bivalve assemblages (Wollemann 1892). Although these differences in macrobenthos assemblages may be partly explained by substrate changes, the-albeit scattered-occurrence of coralline sponges in the Numismalismergel Formation suggest an influx of warmer seawater from Tethyan regions in the Early Pliensbachian.

In this context, the new finds of the bivalve Oxytoma (Palmoxytoma) are of palaeozeanographic significance. This taxon has been extensively reviewed by Damborenea (1993, 2002) as a bivalve with a pronounced bipolar distribution, including occurrences from southern South America and New Zealand, and from northern boreal areas (NE Siberia, far-east Russia, Japan, Canada) and England, Sweden, and France.

Accordingly, the occurrence of Oxytoma (Palmoxytoma) at the top of the "Belemniten-Schichten" in Northern Germany may indicate an influx of cool seawater to the eastern part of the NW European Shelf at the base of the Upper Pliensbachian (Fig. 5), i.e. just before the onset of the Amaltheenton formation. This carbonate top bed of the "Belemniten-Schichten" consists of echinoderm wacke/ packstones with reduced macrobenthos species richness. Indeed, at Beierstedt this condensed bed contained only five bivalve species, compared with 20 bivalve species in the condensed Lower Pliensbachian carbonate bed below (Table 1). Certainly, these species counts provide only a first hint, and quantitative benthos analysis of sections less affected by time-averaging (Fürsich and Aberhan 1990) are required to verify this trend. This supposed cool water current may have extended (during the upper Margaritatus to Spinatum Zones) farther south to eastern Bavaria and southeastern France, as suggested by the specimens reported by von Ammon in von Gümbel (1891), by Dumortier (1857, 1869) and by Rulleau (2007) (Fig. 5).

Continuing cool water conditions during deposition of the Amaltheenton formation in Northern Germany are evident from glendonites, which have been reported from the upper part of the Amaltheenton formation (motorway A 39 at Wolfsburg; Luppold and Teichert 2007), although their significance as an indicator of low temperatures has subsequently been questioned by the same authors (Teichert and Luppold 2009). However, the temperature-pressure stability field of ikaite, the precursor of glendonites, is well constrained, and the significance of the associated species-rich and supposed thermophile microfauna mentioned by these authors must be verified.

For the Rhaetian-Hettangian boundary, the palaeoenvironmental implications of the Oxytoma (Palmoxytoma) occurrences are more difficult to determine. Assuming a cool water preference of Oxytoma (Palmoxytoma) for this time interval also, the occurrences within the Alpine region may point to a cool deeper-water setting, or alternatively to a global cooling interval. Although the causes of the Triassic-Jurassic boundary extinction event are still under discussion (Tanner et al. 2004), climatic fluctuations with a short-term cooling period (induced by aerosols) immediately after the negative $\delta^{13} \mathrm{C}$ excursion, followed by a warming period (induced by increased atmospheric $\mathrm{CO}_{2}$ ) seem well constrained (reviewed by, e.g., Wignall 2001; Guex et al. 2004; Pieńkowski et al. 2008). Also, the higher extinction rate of tropical than non-tropical genera in the Rhaetian point to a palaeoclimatic factor in the end-Triassic mass extinction (Kiessling and Aberhan 2007). A short-term cooling interval may hence be assumed for the English Pre-Planorbis beds and the Southwest German Psilonotenkalk, both deposited in shallow-water settings on the NW European Shelf. However, the occurrence of the coral Isastrea in the Psilonotenkalk (Schweigert et al. 2010), a zooxanthellate warm-water coral rather than an azooxanthellate cool-water coral, challenges this hypothesis. Here, further investigations are required to assess faunal mixing by reworking of stratigraphically older material into the transgressive Psilonoten Limestone.

\section{Conclusions}

Oxytoma (Palmoxytoma) cygnipes (Young \& Bird, 1822) from the Lower Jurassic of Northern Germany (to be precise, from the basal Upper Pliensbachium), is described and illustrated for the first time. Comparison of published specimens of Oxytoma (Palmoxytoma) suggests there is only one species in the Lower Jurassic, i.e. cygnipes (Young \& Bird, 1822). This species ranges from the Rhaetian-Hettangian boundary to the Upper Pliensbachian, probably extending into the Toarcian. A review of published occurrences on the Early Jurassic NW European Shelf indicates two distinct stratigraphic intervals: the Rhaetian-Hettangian boundary and the Upper Pliensbachian. The occurrence of Oxytoma (Palmoxytoma) cygnipes at the base of the Upper Pliensbachian, just before the onset of the Amaltheenton sedimentation, is interpreted as reflecting an influx of cool water from the Boreal Ocean on to the eastern NW European Shelf. This cool water current may have extended southwards as far as Southern Germany, with a possible counter current on the western shelf parts. For the occurrences of the species at the TriassicJurassic boundary of the NW European Shelf, a short-term cooling interval at the same time as the extinction event might provide an explanation.

Acknowledgments We are indebted to Fritz-Hermann Müller, Beierstedt and Joachim Reitner, University of Göttingen, for their generous support of the field campaign at Beierstedt. Alexander Satmari, 
Göttingen, prepared the thin-sections. Winfried Werner and Erwin Geiss, München, carried out a search for Oxytoma (Palmoxytoma) in the Gümbel collection of the Bavarian Geological Survey. Christine Heim, Göttingen, helped with translating Swedish publications. We are indebted to Louis Rulleau, Chasselay, for providing detailed information on the occurrence of Oxytoma (Palmoxytoma) in the region of Lyon. Günter Schweigert and Philipe Havlik kindly provided access to original specimens in the collections of Stuttgart and Tübingen, respectively. Franz T. Fürsich, Erlangen, and an anonymous reviewer provided helpful comments, corrections, and suggestions.

Open Access This article is distributed under the terms of the Creative Commons Attribution Noncommercial License which permits any noncommercial use, distribution, and reproduction in any medium, provided the original author(s) and source are credited.

\section{References}

Aberhan, M. 1994. Early Jurassic Bivalvia of northern Chile. Part I. Subclasses Palaeotaxodonta, Pteriomorphia, and Isofilibranchia. Beringeria 13: 3-115.

Aberhan, M. 1998. Early Jurassic Bivalvia of western Canada. Part I. Subclasses Palaeotaxodonta, Pteriomorphia, and Isofilibranchia. Beringeria 21: 57-150.

Ahlberg, A., U. Sivhed, and M. Erlström. 2003. The Jurassic of Skåne, southern Sweden. Geological Survey of Denmark and Greenland Bulletin 1: 527-541.

Ambrose, K. 2001. The lithostratigraphy of the Blue Lias Formation (Late Rhaetian-Early Sinemurian) in the southern part of the English Midlands. Proceedings of the Geologists' Association 112: 97-110.

Arkell, W.J. 1933. The Jurassic System in Great Britain. Oxford: Clarendon Press.

Bjerrum, C.J., F. Surlyk, J.H. Callomon, and R.L. Slingerland. 2001. Numerical paleoceanographic study of the Early Jurassic transcontinental Laurasian Seaway. Paleoceanography 16: 390-404.

Bloos, G. 1999. Neophyllites (Ammonoidea, Psiloceratidae) in the earliest Jurassic of South Germany). Neues Jahrbuch für Geologie und Paläontologie Abhandlungen 211: 7-29.

Brandt, K. 1985. Sea-level changes in the Upper Sinemurian and Pliensbachian of Southern Germany. Lecture Notes in Earth Sciences 1: 113-126.

Brauns, D.A. 1871. Der untere Jura im nordwestlichen Deutschland von der Grenze der Trias bis zu den Amaltheenthonen, mit besonderer Berücksichtigung seiner Molluskenfauna; nebst Nachträgen zum Mittleren Jura. Braunschweig: Vieweg.

Bruguiere, J.G. 1789. Encyclopédie Méthodique. Histoire Naturelle des Vers. Tome 1. Paris: Panckoucke.

Cope, J.C.W. 1991. Discussion on correlation of the Triassic-Jurassic boundary in England and Austria. Journal of the Geological Society 148: 420-422.

Cox, L.R. 1961. New genera and subgenera of Mesozoic Bivalvia. Palaeontology 4: 592-598.

Damborenea, S.E. 1987. Early Jurassic Bivalvia of Argentina, Pt. 2: Superfamilies Pteriacea, Buchiacea and part of Pectinacea. Palaeontographica A 199: 113-216.

Damborenea, S.E. 1993. Early Jurassic South American pectinaceans and circum-Pacific palaeobiogeography. Palaeogeography, Palaeoclimatology, Palaeoecology 100: 109-123.

Damborenea, S.E. 2002. Early Jurassic bivalves of Argentina, Pt. 3: Superfamilies Monotoidea, Pectinoidea, Plicatuloidea and Dimyoidea. Palaeontographica A 265: 1-119.
Damborenea, S.E., and M.O. Manceñido. 1992. A comparison of Jurassic marine benthonic faunas from South America and New Zealand. Journal of the Royal Society of New Zealand 22: 131-152.

de Graciansky, P.C., T. Jacquin, and S.P. Hesselbo. 1998. The Ligurian cycle: an overview of Lower Jurassic 2nd order transgressive-regressive facies cycles in western Europe. Special Publication of the Society for Sedimentary Geology 60: 468-479.

Dera, G., E. Pucéat, P. Pellenard, P. Neige, D. Delsate, M.M. Joachimski, L. Reisberg, and M. Martinez. 2009. Water mass exchange and variations in seawater temperature in the NW Tethys during the Early Jurassic: Evidence from neodymium and oxygen isotopes of fish teeth and belemnites. Earth and Planetary Science Letters 286: 198-207.

Dore, A.G. 1991. The structural foundation and evolution of Mesozoic seaways between Europe and the Arctic. Palaeogeography, Palaeoclimatology, Palaeoecology 87: 441-492.

Dumortier, E. 1857. Note sur quelques fossiles peu connus ou mal figurés du Lias moyen. Annales de la Société impériale d'agriculture, d'histoire naturelle et des arts utiles de Lyon:1-23, 8 pls.

Dumortier, E. 1869. Étude paléontologique sur les dépots jurassiques du bassin du Rhone. Troisiéme Partie. Lias-moyen. 45 pls., Paris: Savy.

Ефимова А.Ф., В.П. Кинасов, К.В. Паракецов, И.В. Полуьотко, Ю.С. Репин, and А.С. Дагис. 1968. Полевой Атлас Юрской Фауны и Флоры Северо-Востока СССР. Северо-Восточное ордена Трудового Красного знамени Геологическое Управление, Магаданское Книжное Издательство. [Efimova A.F., Kinasov V.P., Paraketsov K.V., Polubotko I.V., Repin Yu.S. and Dagis A.S. 1968. Field atlas of Jurassic Fauna and Flora of the Northeastern USSR. Northeastern Order of the Red Banner of Labour Geological Institute, Magadan (Magadan book publishing house). In Russian.].

Frebold, H. 1957. The Jurassic Fernie Group in the Canadian Rocky Mountains and Foothills. Geological Survey of Canada Memoir 287: 1-197.

Fugger, E. 1906. Die Gaisberggruppe. Jahrbuch der kaiserlichköniglichen geologischen Reichsanstalt 56: 213-258.

Fürsich, F.T., and M. Aberhan. 1990. Significance of time-averaging for palaeocommunity analysis. Lethaia 23: 143-152.

Guex, J., A. Morard, A. Bartolini, and E. Morettini. 2001. Découverte d'une importante lacune stratigraphique à la limite DomérienToarcien: Implications paléo-océanographiques. Bulletin de la Société vaudoise des sciences naturelles 87: 277-284.

Guex, J., A. Bartolini, V. Atudorei, and D. Taylor. 2004. Highresolution ammonite and carbon isotope stratigraphy across the Triassic-Jurassic boundary at New York Canyon (Nevada). Earth and Planetary Science Letters 225: 29-41.

Hahn, F.F. 1911. Neue Funde im nordalpinen Lias der Achenseegegend und bei Ehrwald. Neues Jahrbuch für Mineralogie, Geologie und Paläontologie, Beilage-Band 82: 535-577.

Hallam, A. 1967. An environmental study of the Upper Domerian and Lower Toarcian in Great Britain. Philosophical Transactions of the Royal Society of London B 252: 393-445.

Harries, P., and C.T.S. Little. 1999. The early Toarcian (Early Jurassic) and the Cenomanian-Turonian (Late Cretaceous) mass extinctions: similarities and contrasts. Palaeogeography, Palaeoclimatology, Palaeoecology 154: 39-66.

Hesselbo, S.P., and H.C. Jenkyns. 1998. British Lower Jurassic sequence stratigraphy. Special Publication of the Society for Sedimentary Geology 60: 561-581.

Hölder, H. 1953. Oxytoma scania (Lundgren) in der schwäbischen Planorbis-Zone. Neues Jahrbuch für Geologie und Paläontologie Monatshefte 1953:358-364, Stuttgart.

Hölder, H. 1964. Handbuch der Stratigraphischen Geologie IV: Jura. Stuttgart: Enke. 
Howarth, M.K. 1955. Domerian of the Yorkshire Coast. Proceedings of the Yorkshire Geological Society 30: 147-175.

Jeannet, A. 1913. Monographie géologique des Tours d'Aï et des régions avoisinantes (Préalpes vaudoises). 1ère partie: Stratigraphie de la nappe rhétique, du Trias et du Lias des Préalpes médianes et de la zone interne. Beiträge zur geologischen Karte der Schweiz, Neue Folge 34(1): 1-466. 7 pls., Bern: A. Francke.

Kiessling, W., and M. Aberhan. 2007. Environmental determinants of marine benthic biodiversity dynamics through Triassic-Jurassic time. Paleobiology 33: 414-434.

Коновалова И.В. and П.В. Маркевич. 2004. Южное Приморье. - [в:] Маркевича П.В. \& Захарова Ю.Д. (редакторы): Триас и юра Сихотэ-Алиня. Книга 1. Терригенный комплекс: 233-314, Владивосток (Дальнаука). [Konovalova I.V. and Markevich P.V. 2004. Southern Littoral.-[In:] Markevich P.V. and Zakharov Y.D. (eds.): Triassic and Jurassic of the SikhoteAlin.—Book 1 Terrigenous Assemblage: 233-314, Vladivostok: Dalnauka. In Russian.].

Kuhn, O. 1935. Weitere Beiträge zur Fauna des untersten Lias in Schwaben und Franken. Jahreshefte des Vereins für vaterländische Naturkunde in Württemberg 91: 2-18.

Kuhn, O. 1936. Die Fauna des Amaltheentons (Lias $\delta$ ) in Franken. Neues Jahrbuch für Mineralogie, Geologie und Paläontologie, Beilage-Band 75 (Abt. B Geologie und Paläontologie):231-311.

Lange, W. 1952. Der untere Lias am Fonsjoch (östliches Karwendelbirge) und seine Ammonitenfauna. Palaeontographica A 102: 49-162.

Lundgren, B. 1881. Undersökningar öfver Molluskfaunan i Sveriges äldre Mesozoiska Bildningar. Sveriges Geologiska Undersökning 47 [Lunds Universitets Arsskrift 17]: 1-57, 6 pls., Lund: Fr. Berling.

Lundgren, B. 1888. Öfversigt at sveriges mesozoiska Bildningar. Lunds Universitets Arsskrift, II. Mathematik och Naturvetenskap 24: 1-37.

Luppold, F.W., and B.M.A. Teichert. 2007. Glendonite im Jura (Lias, Oberes Pliensbachium) Norddeutschlands. Geowissenschaftliche Mitteilungen (GMIT) 28: 26-27.

McRoberts, C.A., H. Furrer, and D.S. Jones. 1997. Palaeoenvironmental interpretation of a Triassic-Jurassic boundary section from Western Austria based on palaeoecological and geochemical data. Palaeogeography, Palaeoclimatology, Palaeoecology 136: 79-95.

Meyer, R.K.F. and W. Bauberger. 1998. Geologische Karte von Bayern 1:25000. Erläuterungen zum Blatt Nr. 6739 Bruck i.d.Opf. 1 map, München: Bayerisches Geologisches Landesamt.

Милова, Л.В. 1976. Стратиграфия и двустворчатые моллюски триасово-юрских отложений Северного Приохотья. - Академия наук СССР, Дальневосточный Научный Центр, СевероВосточный комплексный научно-исследовательский институт, Труды, Выпуск 65: 1-108, Издательство "Наука", Москва. [Milova, L.V. 1976. Stratigraphy and bivalve mollusks of the Triassic- Jurassic deposits of northern Priokhot'ya. USSR Academy of Sciences, Far-Eastern Scientific Center, Northeastern Interdisciplinary Research Institute, Transactions 65: 1-108, Moscow: Nauka. In Russian].

Moberg, J.C. 1888. Om lias i sydöstra skåne. Sveriges Geologiska Undersökning C 99: 1-86.

Monke, H. 1889. Die Liasmulde von Herford in Westfalen. Verhandlungen des Naturhistorischen Vereins der Rheinlande, Westfalens und des Reg.-Bezirks Osnabrück 45(5): 1-114.

Mönnig, E. 2005. Der Jura von Norddeutschland in der Stratigraphischen Tabelle von Deutschland 2002. Newsletters on Stratigraphy 41: 253-261.

Neumayr, M. 1879. Zur Kenntnis des unteren Lias in den Nordalpen. Abhandlungen der Kaiserlich-Königlichen Geologischen Reichsanstalt 7(5): 1-46.
Oppel, A. 1856-1858. Die Juraformation Englands, Frankreichs und des südwestlichen Deutschlands. Württembergische naturwissenschaftliche Jahreshefte 12-14:1-857.

Phillips, J. 1829. Illustrations of the Geology of Yorkshire. Part 1, The Yorkshire Coast. London: Murray.

Pieńkowski, G., M.E. Schudack, P. Bosák, R. Enay, A. FeldmanOlszewska, J. Golonka, J. Gutowski, G.F.W. Herngreen, P. Jordan, M. Krobicki, B. Lathuiliere, R.R. Leinfelder, J. Michalík, E. Mönnig, N. Noe-Nygaard, J. Pálfy, A. Pint, M.W. Rasser, A.G. Reisdorf, D.U. Schmid, G. Schweigert, F. Surlyk, A. Wetzel, and T.E. Wong. 2008. Jurassic. In The geology of Central Europe. Volume 2: Mesozoic and Cenozoic, ed. T. McCann, 823-922. Geological Society London.

Poulton, T.P. 1991. Hettangian through Aalenian (Jurassic) guide fossils and biostratigraphy, northern Yukon and adjacent Northwest Territories. Geological Survey of Canada Bulletin 410: $1-95$.

Price, G.D. 1999. The evidence and implications of polar ice during the Mesozoic. Earth-Science Reviews 48: 183-210.

Quenstedt, F.A. 1867. Handbuch der Petrefaktenkunde. 2nd ed., 86 pls, Tübingen: Laupp.

Quenstedt, F.A. 1883-1885. Die Ammoniten des Schwäbischen Jura. Band 1: Der Schwarze Jura (Lias). 54 pls, Stuttgart: Schweizerbart.

Rawson, P.F., and J.K. Wright. 1996. Jurassic of the Cleveland Basin, North Yorkshire. In Field geology of the British Jurassic, ed. P.D. Taylor, 173-208. London: Geological Society.

Reyment, R.A. 1959. On Liassic ammonites from Skåne, southern Sweden. Stockholm Contributions in Geology 2(6): 103-157.

Riccardi, A.C., S.E. Damborenea, M.O. Manceñido, and S.C. Ballent. 1991. Hettangian and Sinemurian (Lower Jurassic) biostratigraphy of Argentina. Journal of South American Earth Sciences 4: 159-170.

Richards, P.C. 1990. The early to mid-Jurassic evolution of the northern North Sea. Geological Society, London, Special Publications 55: 191-205.

Riding, J.B., and R.N.L.B. Hubbard. 1999. Jurassic (ToarcianKimmeridgian) dinoflagellate cysts and paleoclimates. Palynology 23: $15-30$.

Rosenkrantz, A. 1934. The Lower Jurassic rocks of East Greenland, Part I. Meddelelser om Grønland 110: 1-150.

Rulleau, L. 2007. Biostratigraphie et paléontologie de la Région lyonnaise. Tome II: du Socle au Lias moyen. 57 pl., Section Géologie et Paléontologie du Comité d'Entreprise Lafarge Ciments (Dedale Editions).

Schweigert, G., and J. Klaschka. 2011. Eine Schwanenfuß-Muschel zu Gast im Schwäbischen Jura. Fossilien 28(4): 223-226.

Schweigert, G., T. Balle, and H. Miksche. 2010. Einsame Koralle. Fossilien 27(6): 348-353.

Sey, I.I., Y.S. Repin, E.D. Kalacheva, T.M. Okuneva, K.V. Paraketsov, and I.V. Polubotko. 1992. Eastern Russia. In The Jurassic of the circum-Pacific. World and regional geology 3 (International Geological Correlation Programme project 171), ed. G.E.G. Westermann, 225-245, Cambridge: Cambridge University Press.

Sivhed, U. 1984. Litho- and biostratigraphy of the Upper TriassicMiddle Jurassic in Scania, southern Sweden. Sveriges Geologiska Undersökning C 806: 1-28.

Sowerby, J. 1812-1822. The mineral conchology of Great Britain. Vols. 1-4: pls. 1-383, London.

Steel, R., and A. Ryseth. 1990. The Triassic-Early Jurassic succession in the northern North Sea; megasequence stratigraphy and intraTriassic tectonics. Geological Society, London, Special Publications 55: 139-168.

Stutchbury, S. 1839. Description of a new fossil Avicula, from the Lias Shale of Somersetshire. Magazine of Natural History (New Series) 3: 163-164. 
Tanner, L.H., S.G. Lucas, and M.G. Chapman. 2004. Assessing the record and causes of Late Triassic extinctions. Earth Science Reviews 65: 103-139.

Tate, R., and J.E. Blake. 1876. The Yorkshire Lias. London: John von Vorst.

Teichert, B.M.A. and F.W. Luppold. 2009. Glendonite formation in Early Jurassic dark shales: Evidence for methane seepage in northern Germany. Geochimica et Cosmochimica Acta 73(13, Suppl 1):A1319.

Thomas, E. 1924. Genetische Betrachtungen über die Lias-und Neokomablagerungen am Fallstein und ihre Eisenerze. Jahrbuch des Halleschen Verbandes für die Erforschung der mitteldeutschen Bodenschätze und ihrer Verwertung 4: 74-155.

Trechmann, C.T. 1923. The Jurassic rocks of New Zealand. Quarterly Journal of the Geological Society London 79(3): 246-286.

Troedsson, G. 1951. On the Höganäs Series of Sweden (Rhaeto-Lias). Lunds Universitets Arsskrift N. F. 2, 47(1):1-268.

van de Schootbrugge, B., T. Bailey, Y. Rosenthal, M.E. Katz, J.D. Wright, S. Feist-Burkhardt, K.G. Miller, and P.G. Falkowski. 2005. Early Jurassic climate change and the radiation of organicwalled phytoplankton in the Tethys Ocean. Paleobiology 31: 73-97.

von Gümbel, C.W. 1891. Geognostische Beschreibung des Koenigreichs Bayern. 4. Abtheilung, Geognostische Beschreibung der Fränkischen Alb (Frankenjura) mit dem anstossenden fränkischen Keupergebiete. Kassel: Fischer [Reprint 1998 Pfeil-Verlag München].

von Hillebrandt, A.v., L. Krystyn, and W.M. Kuerschner. 2007. A candidate GSSP for the base of the Jurassic in the Northern Calcareous Alps (Kuhjoch section, Karwendel Mountains, Tyrol, Austria). ISJS Newsletter 34(1): 2-20. von Koenen, A. 1907. Erläuterungen zur geologischen Specialkarte von Preussen und den Thüringischen Staaten. Blatt No. 28 Göttingen. 2nd ed. Berlin: Schropp.

von Schlotheim, E.F. 1820. Die Petrefactenkunde auf ihrem jetzigen Standpunkte durch die Beschreibung seiner Sammlung versteinerter und fossiler Überreste des Thier- und Pflanzenreichs der Vorwelt erläutert. 15 pls., Gotha: Becker.

von Seebach, K. 1864. Der Hannoversche Jura. 10 pls., Berlin: Hertz.

Westermann, G.E.G. 1993. Global bio-events in mid-Jurassic ammonites controlled by seaways. Systematics Association Special Volume 47: 187-226.

Wignall, P.B. 2001. Large igneous provinces and mass extinctions. Earth-Science Reviews 53: 1-33.

Wollemann, A. 1892. Verzeichnis der im Eisenstein des Lias $\gamma$ von Rottorf am Kley bei Helmstedt bisland gefundenen Versteinerungen. Verhandlungen des naturhistorischen Vereins der preussischen Rheinlande, Westfalens und des Reg.-Bezirks Osnabrück 49: 107-147.

Young, G. and J. Bird. 1822. A geological survey of the Yorkshire coast: describing the strata and fossils occurring between the Humber and the Tees, from the German Ocean to the plain of York. 17 pls., Whitby.

Young, G. and J. Bird. 1828. A geological survey of the Yorkshire coast: describing the strata and fossils occurring between the Humber and the Tees, from the German Ocean to the plain of York. 2nd ed., 17 pls., Whitby.

Ziegler, P.A. 1988. Evolution of the Arctic-North Atlantic and the Western Tethys. American Association of Petroleum Geologists Memoir 43: 30 enclosures, Tulsa.

Ziegler, P.A. 1990. Geological atlas of western and central Europe. 2nd ed., 56 enclosures, Den Haag: Shell Internationale Petroleum Maatschapij B.V. 